Article

\title{
Surface Features of Fluorapatite and Dolomite in the Reverse Flotation Process Using Sulfuric Acid as a Depressor
}

\author{
Heng Zou ${ }^{1}$, Qinbo Cao ${ }^{1,2, *}$, Dianwen Liu ${ }^{1,2, *}$, Xingcai Yu ${ }^{1}$ and Hao Lai ${ }^{1}$ \\ 1 Faculty of Land Resources Engineering, Kunming University of Science and Technology, Kunming 650093, \\ China; zh@kmust.edu.cn (H.Z.); kgyuxingcai@163.com (X.Y.); kjlaihao@163.com (H.L.) \\ 2 State Key Laboratory of Complex Nonferrous Metal Resources Clean Utilization, Kunming 650093, China \\ * Correspondence: cabdxx@163.com (Q.C.); ldwkust@126.com (D.L.); Tel.: +86-0871-65187068 (Q.C.); \\ +86-0871-65915828 (D.L.)
}

Received: 29 November 2018; Accepted: 6 January 2019; Published: 11 January 2019

\begin{abstract}
The surface features of fluorapatite $\left(\mathrm{FA}, \mathrm{Ca}_{5}\left(\mathrm{PO}_{4}\right)_{3} \mathrm{~F}\right)$ and dolomite $\left(\mathrm{CaMg}\left(\mathrm{CO}_{3}\right)_{2}\right)$ conditioned with sulfuric acid $\left(\mathrm{H}_{2} \mathrm{SO}_{4}\right)$ were examined through flotation experiments, contact angle tests, time-of-flight secondary ion mass spectrometry (TOF-SIMS), and FTIR experiments. The flotation and contact angle results suggested that oleate insufficiently adsorbed onto the $\mathrm{H}_{2} \mathrm{SO}_{4}$-treated FA surface such that the FA surface remained hydrophilic. However, using oleate as a collector, the recovery and hydrophobicity of $\mathrm{H}_{2} \mathrm{SO}_{4}$-treated dolomite were satisfactory. TOF-SIMS and FTIR studies indicated that sulfate anion bound with Ca atoms on the FA surface, which hindered oleate adsorption onto the FA surface. Meanwhile, sulfate anion and oleate species appeared on the dolomite surface, thereby generating a hydrophobic dolomite and also a satisfactory recovery.
\end{abstract}

Keywords: flotation; fluorapatite; dolomite; sulfuric acid; depressor

\section{Introduction}

Dolomite $\left(\mathrm{CaMg}\left(\mathrm{CO}_{3}\right)_{2}\right)$ is a critical gangue mineral in most phosphate deposits in China [1]. The separation of dolomite from apatite determines the success of the phosphate flotation to some extent. Separating dolomite from apatite in an efficient and economically way is difficult for a collophane ore. Collophane is a type of unique phosphate ore containing cryptocrystalline apatite [2]. In a collophane ore, extra-fine minerals of apatite and dolomite may associate with each other to form aggregations [3,4]. The separation of extra-fine apatite from dolomite is considerably difficult.

Flotation is the main technique for upgrading collophane ore. In the direct flotation scheme, apatite is floated with fatty acid collectors in a basic solution [5]. Dolomite can also be floated with the collectors, because the traditional fatty acid collectors can adsorb not only on the apatite surface but also on the dolomite surface. Thus, depressors of dolomite, such as starch, are commonly needed [2]. Considerable selective collectors and efficient depressors have been developed for the flotation separation of apatite from dolomite or calcite [6,7]. These new reagents have great potential to be used in phosphate plants.

With regard to low-grade collophane ore, obtaining a satisfactory phosphate concentrate with a single direct flotation method is difficult because the dolomite content is relatively high in the ore, and thus cannot be completely depressed. Therefore, a reverse flotation strategy is used to separate dolomite from apatite in phosphate flotation plants [8]. Using such strategy, apatite is depressed with sulfuric or phosphoric acid $\left(\mathrm{H}_{2} \mathrm{SO}_{4} / \mathrm{H}_{3} \mathrm{PO}_{4}\right)$, whereas dolomite can be floated with a fatty acid collector, such as oleate, in a weak acidic solution [9]. $\mathrm{H}_{2} \mathrm{SO}_{4}$ compared to $\mathrm{H}_{3} \mathrm{PO}_{4}$ is a more prevalent 
depressor for apatite in industry due to its relatively lower price. This method has been widely used in the beneficiation of collophane ores in China.

Despite the successful industry practice to separate dolomite from apatite with the reverse flotation strategy, the depressing mechanism of $\mathrm{H}_{2} \mathrm{SO}_{4}$ has not yet been fully understood. The flotation of fluorapatite ( $\left.\mathrm{FA}, \mathrm{Ca}_{5}\left(\mathrm{PO}_{4}\right)_{3} \mathrm{~F}\right)$ with fatty acid collectors, such as oleate, is carried out in a basic solution. The adsorption of oleate onto the FA surface is governed by the chemisorption of oleate ion and surface/bulk precipitation of calcium dioleate salt on the surface $[10,11] . \mathrm{SO}_{4}{ }^{2-}$ may react with $\mathrm{Ca}^{2+}$ on the FA surface to form $\mathrm{CaSO}_{4}$ species due to the low solubility of $\mathrm{CaSO}_{4}$ [8]. Thus, oleate cannot further adsorb on the Ca sites on the FA surface. However, no further direct evidence has been provided to validate this opinion in previous studies.

$\mathrm{H}_{2} \mathrm{SO}_{4}$ cannot prevent the flotation of dolomite with oleate as a collector. Interestingly, oleate can still adsorb onto the $\mathrm{H}_{2} \mathrm{SO}_{4}$-treated dolomite surface. The possible occurrence of precipitation of $\mathrm{CaSO}_{4}$ on the dolomite surface is uncertain due to the instability of dolomite in an acidic solution. Moreover, the $\mathrm{pH}$ of phosphate slurry with $\mathrm{H}_{2} \mathrm{SO}_{4}$ is much lower than that in the direct flotation of apatite. The $\mathrm{pH}$ of the solution is a vital factor in determining the adsorption state of oleate on a mineral surface [12]. However, the adsorption state of oleate on the $\mathrm{H}_{2} \mathrm{SO}_{4}$-treated dolomite surface has yet to be reported in the literature.

Current knowledge regarding the effects of $\mathrm{H}_{2} \mathrm{SO}_{4}$ on the flotation of apatite and dolomite is lacking. The present study was aimed at investigating the adsorption behavior of oleate on the $\mathrm{H}_{2} \mathrm{SO}_{4}$-treated fluorapatite (FA) and dolomite surfaces. Firstly, flotation and contact angle experiments were employed to assess the depressing capacity of $\mathrm{H}_{2} \mathrm{SO}_{4}$ for the flotation of FA/dolomite. Furthermore, the time-of-flight secondary ion mass spectrometry (TOF-SIMS) technique was used to reveal the distribution of $\mathrm{SO}_{4}{ }^{2-}$ and collector on the minerals' surfaces. The oleate species on the dolomite surface were further determined with FTIR spectroscopy analysis.

\section{Materials and Methods}

\subsection{Minerals and Reagents}

The FA and dolomite pebbles (purities $>98 \%$ ) from the Geological Museum of Yunnan Province, China were used in this study. The analytical reagent (AR) grade reagents, including sodium oleate $(\mathrm{NaOl})$ and concentrated $\mathrm{H}_{2} \mathrm{SO}_{4}$ were purchased from Sinopharm Chemical Reagent Co., Ltd. (Shanghai, China). All experiments were conducted with deionized (DI) water at $23^{\circ} \mathrm{C}$.

\subsection{Flotation Experiments}

Flotation tests were conducted with an XFGC II flotation machine (Jilin Province Ore Exploration Machinery Factory, Changchun, China) and a $40 \mathrm{~mL}$ flotation cell. Two grams of pure mineral was used in each flotation experiment. The dolomite or FA sample was conditioned with $\mathrm{H}_{2} \mathrm{SO}_{4}$ solution for $3 \mathrm{~min}$ in the flotation cell, after which the desired amount of oleate was added into the flotation cell. The condition time for the collector was also $3 \mathrm{~min}$. Air was used in the flotation tests at a flow rate of $20 \mathrm{~mL} / \mathrm{min}$, while the flotation time was controlled at $1 \mathrm{~min}$. Each test was repeated three times.

\subsection{Contact Angle Measurements}

The contact angle experiments were performed with a GBX $3 S$ instrument (GBS, Dublin, Ireland). The FA/dolomite pebble was well polished with 2000-, 4000-, and 6000-grit $\mathrm{Al}_{2} \mathrm{O}_{3}$ sand paper before each measurement. After the pebble had been treated with $\mathrm{H}_{2} \mathrm{SO}_{4}$ solution for 3 min and then with the collector for another $3 \mathrm{~min}$, the crystal was air-dried for further measurement. A DI water droplet of approximately $2 \mathrm{~mm}$ was induced onto the crystal surface to generate the three-phase contact line. Each sample was measured three times, and the mean values were reported. The error of the measurements was less than $\pm 3^{\circ}$. 


\subsection{TOF-SIMS Analysis}

A TOF-SIM 5 (ION-TOF GmbH, Münster, Germany) was used in the tests. The surface images were analyzed with the spectrometry model using $\mathrm{Bi}_{3}{ }^{++}$primary ions $(15 \mathrm{keV})$, and a $500 \times 500 \mu \mathrm{m}^{2}$ area on the mineral surface was measured. In the depth profiling tests, the $\mathrm{Cs}^{+}$beam and non-interlaced model were used to determine the 3D distribution of secondary ions on the mineral surface. The sputter crater area was $300 \times 300 \mu \mathrm{m}^{2}$, and a $100 \times 100 \mu^{2}$ area was rastered over with a $\mathrm{Bi}_{3}{ }^{++}$beam with the spectrometry model. The well-polished FA and dolomite crystals were conditioned with the $\mathrm{H}_{2} \mathrm{SO}_{4}$ solution and/or the oleate solution for the TOF-SIMS study. The condition times were the same as those for the contact-angle measurements.

\subsection{Attenuated Total Reflection (ATR)-FTIR Spectroscopy Experiments}

An Avatar 300 (Thermo Electron Crop., Waltham, MA, USA) was used to record the FTIR spectra of the FA and dolomite samples. The FA and dolomite samples $(1 \mathrm{~g},-5 \mu \mathrm{m})$ were prepared by two different methods: (1) conditioned with $100 \mathrm{~mL}$ of $\mathrm{H}_{2} \mathrm{SO}_{4}$ solution $\left(2 \times 10^{-3} \mathrm{~mol} / \mathrm{L}\right)$ for $3 \mathrm{~min}$; (2) conditioned with $100 \mathrm{~mL}$ of $\mathrm{H}_{2} \mathrm{SO}_{4}$ solution $\left(2 \times 10^{-3} \mathrm{~mol} / \mathrm{L}\right)$ for $3 \mathrm{~min}$, and then with oleate for $40 \mathrm{~min}$. In the second method, the desired amount of oleate was directly added into the $\mathrm{H}_{2} \mathrm{SO}_{4}$ solution to obtain a collector solution. After the conditioning with reagent solution, the suspension was filtered and then air-dried for the analysis. A ZnSe multiple internal reflection prism (Thermo Electron Crop., Waltham, MA, USA) was used to measure the ATR-FTIR spectra. The ZnSe prism was well cleaned with acetone, ethanol, and DI water before each measurement. The ATR-FTIR spectra were recorded at room temperature by co-addition of 300 interferograms at a resolution of $2 \mathrm{~cm}^{-1}$.

\section{Results and Discussion}

\subsection{Flotation Behavior}

The influence of the $\mathrm{H}_{2} \mathrm{SO}_{4}$ dosage on the $\mathrm{FA}$ /dolomite flotation was examined using a laboratory mechanical flotation-machine. The flotation results only with oleate at natural $\mathrm{pH}$ (about 6.5) are also reported. In terms of FA, the recovery was about $30 \%$ with $1 \times 10^{-4} \mathrm{~mol} / \mathrm{L}$ of oleate at the natural $\mathrm{pH}$ (Figure 1), consistent with a previous report [12]. Moreover, the condition with $\mathrm{H}_{2} \mathrm{SO}_{4}$ led to an obviously reduction in FA recovery; the FA recoveries were $<10 \%$ when the $\mathrm{H}_{2} \mathrm{SO}_{4}$ concentration was $\geq 1 \times 10^{-3} \mathrm{~mol} / \mathrm{L}$. A similar trend was found for FA with $2 \times 10^{-4} \mathrm{~mol} / \mathrm{L}$ of oleate, FA could not be efficiently collected by the collector when the $\mathrm{H}_{2} \mathrm{SO}_{4}$ concentration was $\geq 1 \times 10^{-3} \mathrm{~mol} / \mathrm{L}$.

In contrast, the treatment with $\mathrm{H}_{2} \mathrm{SO}_{4}$ slightly improved the flotation of dolomite. At each examined collector concentration $\left(1 \times 10^{-4} \mathrm{~mol} / \mathrm{L}\right.$ and $\left.2 \times 10^{-4} \mathrm{~mol} / \mathrm{L}\right)$, the recovery of dolomite treated with $1 \times 10^{-3} \mathrm{~mol} / \mathrm{L} \mathrm{H}_{2} \mathrm{SO}_{4}$ increased by $5-10 \%$ compared to that without $\mathrm{H}_{2} \mathrm{SO}_{4}$ treatment.

The carbonate ions on the dolomite surface are unstable in acidic solution and can be dissociated into $\mathrm{H}_{2} \mathrm{O}$ and $\mathrm{CO}_{2}$. Thus, a considerable number of metal ions on the surface might be exposed to the solution, thereby providing substantial adsorption sites for the adsorption of oleate. Moreover, the dissolved metal ions may also favor the adsorption of collector to some extent [8]. In this regard, the treatment with $\mathrm{H}_{2} \mathrm{SO}_{4}$ could slightly enhance the dolomite flotation using oleate as a collector.

In addition, the separation of dolomite from FA was further investigated by the flotation tests using a 1:1 mixture of dolomite and FA. The concentration of oleate was $2 \times 10^{-4} \mathrm{~mol} / \mathrm{L}$ in such tests. The recovery of $\mathrm{MgO}$ was close to that of $\mathrm{P}_{2} \mathrm{O}_{5}$ in the absence of $\mathrm{H}_{2} \mathrm{SO}_{4}$, suggesting that oleate is not a selective collector for this flotation system (Table 1). While, the addition of $\mathrm{H}_{2} \mathrm{SO}_{4}$ into the slurry deteriorated the FA flotation. Moreover, the $\mathrm{P}_{2} \mathrm{O}_{5}$ recovery was $<10 \%$ when the $\mathrm{H}_{2} \mathrm{SO}_{4}$ concentration reached $2 \times 10^{-3} \mathrm{~mol} / \mathrm{L}$. It appears that more $\mathrm{H}_{2} \mathrm{SO}_{4}$ was required to depress $\mathrm{FA}$ in the flotation of FA-dolomite mixture, comparing with that in the single-mineral flotation of FA, while the $\mathrm{MgO}$ recoveries were over $69 \%$ regardless of the $\mathrm{H}_{2} \mathrm{SO}_{4}$ concentration. Such results demonstrate again that $\mathrm{H}_{2} \mathrm{SO}_{4}$ can be used as a specific depressor for FA. 


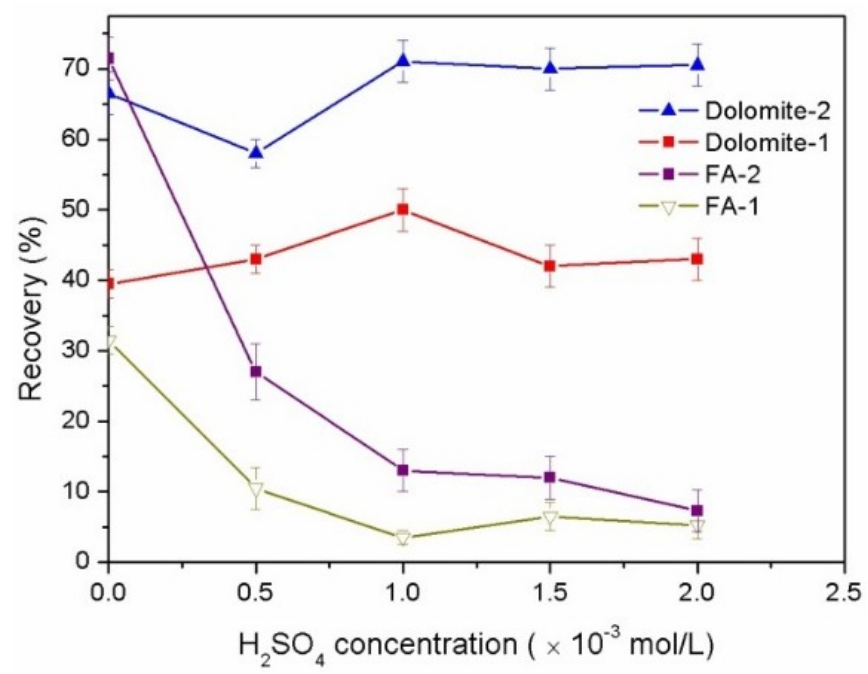

Figure 1. Effect of $\mathrm{H}_{2} \mathrm{SO}_{4}$ concentration on the flotation of FA/dolomite with 1 means $1 \times 10^{-4} \mathrm{~mol} / \mathrm{L}$ and 2 means $2 \times 10^{-4} \mathrm{~mol} / \mathrm{L}$ of oleate.

Table 1. Effect of $\mathrm{H}_{2} \mathrm{SO}_{4}$ concentration on the flotation of FA-dolomite mixture with $2 \times 10^{-4} \mathrm{~mol} / \mathrm{L}$ of oleate.

\begin{tabular}{cccc}
\hline $\mathbf{H}_{2} \mathbf{S O}_{4}$ Concentration (mol/L) & $5 \times 10^{-4}$ & $1 \times 10^{-3}$ & $2 \times 10^{-3}$ \\
\hline $\mathrm{MgO}$ & $72.39 \%$ & $69.45 \%$ & $96.33 \%$ \\
$\mathrm{P}_{2} \mathrm{O}_{5}$ & $80.20 \%$ & $37.61 \%$ & $9.20 \%$ \\
\hline
\end{tabular}

\subsection{Contact Angle Measurements}

The difference in the hydrophobicity of minerals determines the separation efficiency of the flotation technique. The hydrophobicity of FA can be measured with the contact angle method [13]. In this work, this method was used to determine the hydrophobicity of FA/dolomite treated with $\mathrm{H}_{2} \mathrm{SO}_{4}$ and oleate.

Figure 2 shows that the contact angle of FA sharply decreased with an increase in $\mathrm{H}_{2} \mathrm{SO}_{4}$ concentration. When the FA was treated with $1 \times 10^{-3} \mathrm{~mol} / \mathrm{L}$ of $\mathrm{H}_{2} \mathrm{SO}_{4}$, the contact angle was below $25^{\circ}$ using $1 \times 10^{-4}$ or $2 \times 10^{-4} \mathrm{~mol} / \mathrm{L}$ of oleate. These results imply that the usage of $\mathrm{H}_{2} \mathrm{SO}_{4}$ may prevent the adsorption of oleate species onto the FA surface, thereby allowing the FA surface to maintain a hydrophilic state in the slurry.

In contrast, the addition of $\mathrm{H}_{2} \mathrm{SO}_{4}$ into the slurry improved the contact angle of dolomite with $1 \times 10^{-4}$ or $2 \times 10^{-4} \mathrm{~mol} / \mathrm{L}$ of oleate, which is in line with the above flotation results. For each oleate concentration, the contact angle reached the maximum value with $1 \times 10^{-3} \mathrm{~mol} / \mathrm{L}$ of $\mathrm{H}_{2} \mathrm{SO}_{4}$. When the concentration of $\mathrm{H}_{2} \mathrm{SO}_{4}$ was above $1 \times 10^{-3} \mathrm{~mol} / \mathrm{L}$, the contact angle of dolomite was lower than that with $1 \times 10^{-3} \mathrm{~mol} / \mathrm{L}$ of $\mathrm{H}_{2} \mathrm{SO}_{4}$. The $\mathrm{pH}$ of dolomite slurry with $5 \times 10^{-4}$ or $1 \times 10^{-3} \mathrm{~mol} / \mathrm{L}$ of $\mathrm{H}_{2} \mathrm{SO}_{4}$ was approximately 5.5 (Table 2). However, with $1.5 \times 10^{-3}$ or $2 \times 10^{-3} \mathrm{~mol} / \mathrm{L}$ of $\mathrm{H}_{2} \mathrm{SO}_{4}$, the $\mathrm{pH}$ of dolomite slurry was in the $\mathrm{pH}$ range of $4-5$, and precipitation of oleate was observed in the solution. Therefore, oleate species cannot efficiently adsorb on the dolomite surface to produce a highly hydrophobic surface.

The gap in contact angles between FA and dolomite was approximately $83^{\circ}$ when the FA and dolomite were treated by $1 \times 10^{-3} \mathrm{~mol} / \mathrm{L}$ of $\mathrm{H}_{2} \mathrm{SO}_{4}$ and $2 \times 10^{-4} \mathrm{~mol} / \mathrm{L}$ of oleate. Under these conditions, dolomite can be floated by oleate prior to FA. These results further demonstrate that $\mathrm{H}_{2} \mathrm{SO}_{4}$ can be used as a depressor for FA, in accordance with the reverse flotation phenomenon in phosphate plants. 


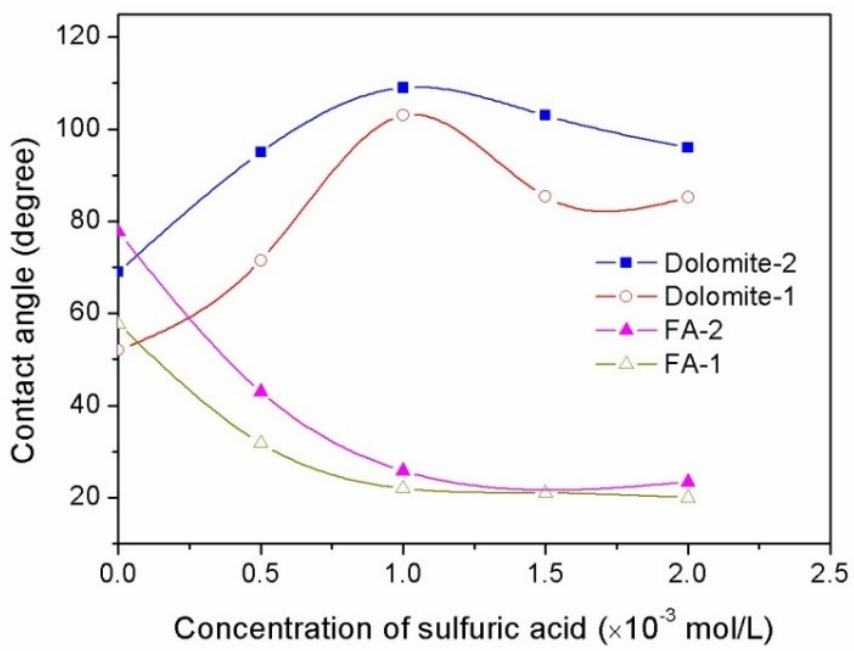

Figure 2. Contact angles of dolomite and fluorapatite conditioned with sulfuric acid and 1 means $1 \times 10^{-4} \mathrm{~mol} / \mathrm{L}$ and 2 means $2 \times 10^{-4} \mathrm{~mol} / \mathrm{L}$ of oleate.

Table 2. The $\mathrm{pH}$ values of dolomite slurry with the addition of $\mathrm{H}_{2} \mathrm{SO}_{4}$.

\begin{tabular}{ccccc}
\hline $\mathbf{H}_{\mathbf{2}} \mathbf{S O}_{4}$ Concentration (mol/L) & $5 \times 10^{-4}$ & $1 \times 10^{-3}$ & $1.5 \times 10^{-3}$ & $2 \times 10^{-3}$ \\
\hline $\mathrm{pH}$ & 5.7 & 5.4 & 4.4 & 4.6 \\
\hline
\end{tabular}

\subsection{TOF-SIMS Analysis}

TOF-SIMS is a highly sensitive technique to determine the 2D/3D distributions of chemical fragments on a solid surface. A beam of primary ions, such as bismuth ions, is used to bombard the solid surface using the TOF-SIMS technique. Atoms or molecular fragments on the solid surface can overcome the surface binding energy to generate secondary ions/molecular fragments due to atomic collisions [14]. According to the mass spectroscopy of the secondary ions/molecular fragments, the distribution of these species on the solid surface can be remodeled [15]. This technique has been successfully used to investigate the surface characters of some minerals in their flotation system [16]. In this context, this method was used to determine the surface features of FA/dolomite conditioned with $\mathrm{H}_{2} \mathrm{SO}_{4}$ and oleate.

\subsubsection{FA Surfaces}

When the $\mathrm{H}_{2} \mathrm{SO}_{4}$-treated FA surface was bombarded with the $\mathrm{Bi}_{3}{ }^{++}$primary ions, three types of secondary ion, namely, $\mathrm{PO}_{3}{ }^{-}, \mathrm{SO}_{4}{ }^{-}$, and $\mathrm{CaO}^{-}$, were emitted from the FA surface (Figure 3). Evidently, $\mathrm{CaO}^{-}$and $\mathrm{PO}_{3}{ }^{-}$came from the original FA surface. The presence of $\mathrm{SO}_{4}{ }^{-}$was due to the adsorbed $\mathrm{SO}_{4}{ }^{2-}$ ions on the FA surface. It is believed that $\mathrm{SO}_{4}{ }^{2-}$ ions interacted with $\mathrm{Ca}^{2+}$ on the FA surface.

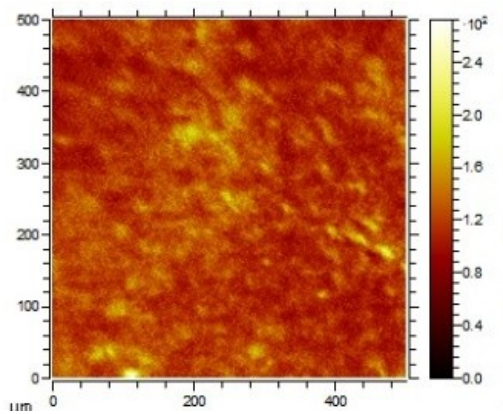

(a)

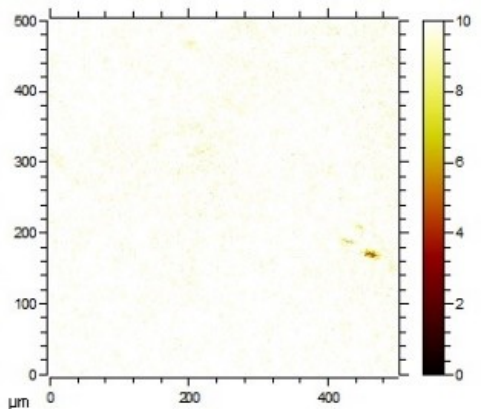

(b)

Figure 3. Cont. 


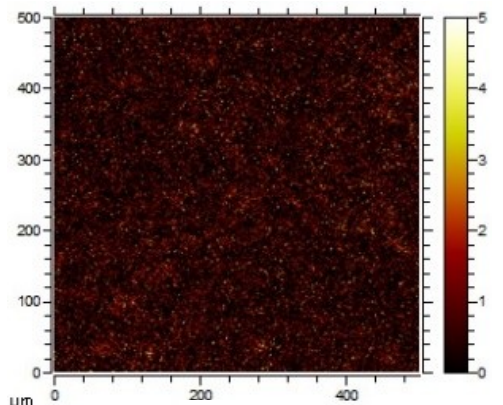

(c)

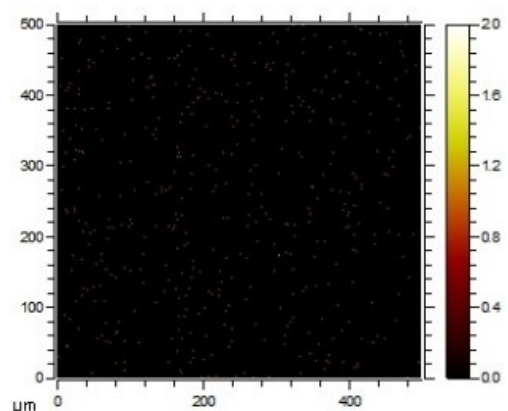

(d)

Figure 3. Two-dimensional distributions of ions on the fluorapatite (FA) surface $\left(500 \times 500 \mu \mathrm{m}^{2}\right)$ treated with $\mathrm{H}_{2} \mathrm{SO}_{4}\left(1 \times 10^{-3} \mathrm{~mol} / \mathrm{L}\right)$ : (a) overlap, (b) $\mathrm{PO}_{3}{ }^{-}$, (c) $\mathrm{SO}_{4}{ }^{-}$, and (d) $\mathrm{CaO}^{-}$.

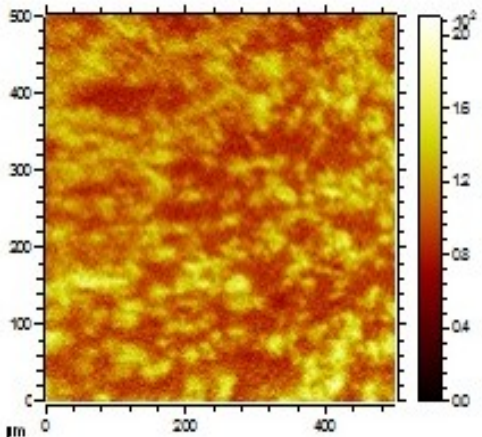

(a)

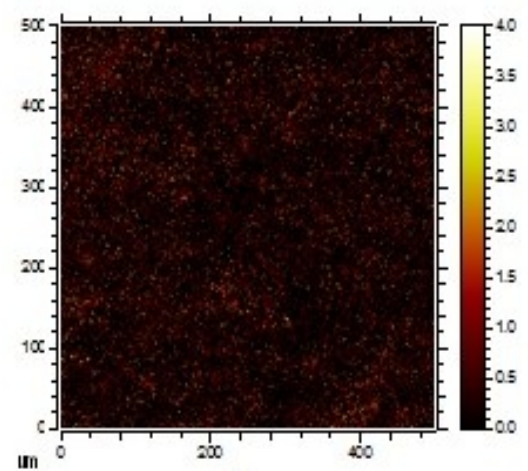

(c)

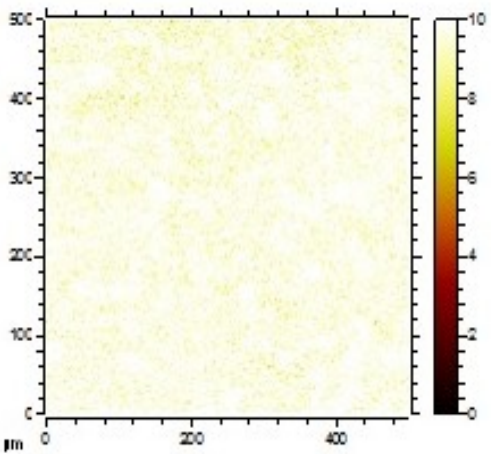

(b)

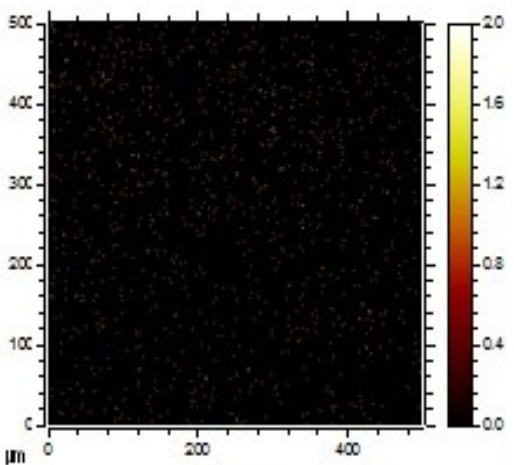

(d)

Figure 4. Two-dimensional distributions of ions on the FA surface $\left(500 \times 500 \mu \mathrm{m}^{2}\right)$ treated with $\mathrm{H}_{2} \mathrm{SO}_{4}$ $\left(1 \times 10^{-3} \mathrm{~mol} / \mathrm{L}\right)$ and oleate $\left(2 \times 10^{-4} \mathrm{~mol} / \mathrm{L}\right)$ : (a) overlap, (b) $\mathrm{PO}_{3}{ }^{-}$, (c) $\mathrm{SO}_{4}{ }^{-}$, and (d) $\mathrm{CaO}^{-}$.

On the FA surface treated with $\mathrm{H}_{2} \mathrm{SO}_{4}\left(1 \times 10^{-3} \mathrm{~mol} / \mathrm{L}\right)$ and oleate $\left(2 \times 10^{-4} \mathrm{~mol} / \mathrm{L}\right), \mathrm{PO}_{3}{ }^{-}$, $\mathrm{SO}_{4}{ }^{-}$, and $\mathrm{CaO}^{-}$species were measured, and their distributions were found to be similar to those on the FA surface only conditioned with $\mathrm{H}_{2} \mathrm{SO}_{4}$ (Figure 4). Moreover, the molecular fragments related to oleate were not detected on the FA surface, thereby indicating that oleate did not occur on the FA surface treated with $\mathrm{H}_{2} \mathrm{SO}_{4}$. Figure 5 further illustrates the 3D results of $\mathrm{PO}_{3}{ }^{-}, \mathrm{SO}_{4}{ }^{-}$, and $\mathrm{CaO}^{-}$ species on the FA surface conditioned with $\mathrm{H}_{2} \mathrm{SO}_{4}$ and oleate. It was found that $\mathrm{PO}_{3}{ }^{-}$and $\mathrm{CaO}^{-}$were well distributed in the bulk phase of FA. In contrast, $\mathrm{SO}_{4}{ }^{-}$only presented on the top of the FA surface in an island-like structure. 
According to the TOF-SIMS and flotation results of the FA samples, it is reasonable to expect that $\mathrm{SO}_{4}{ }^{2-}$ ions reacted with $\mathrm{Ca}$ ions on the top of the $\mathrm{FA}$ surface to generate $\mathrm{CaSO}_{4}$ species. Consequently, oleate cannot further adsorb onto the Ca sites on the $\mathrm{H}_{2} \mathrm{SO}_{4}$-treated FA surface; hence, a poor FA recovery was obtained.

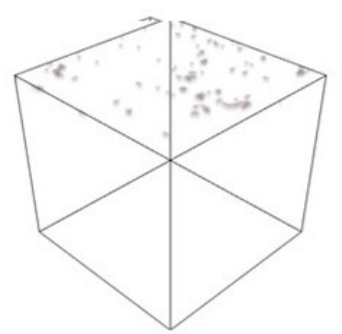

(a)

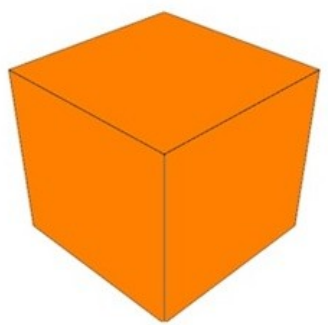

(b)

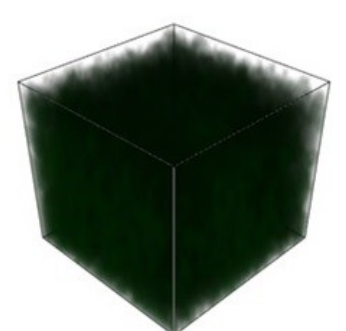

(c)

Figure 5. Three-dimensional distributions of ions on the FA surface treated with $\mathrm{H}_{2} \mathrm{SO}_{4}$ $\left(1 \times 10^{-3} \mathrm{~mol} / \mathrm{L}\right)$ and oleate $\left(2 \times 10^{-4} \mathrm{~mol} / \mathrm{L}\right):(\mathbf{a}) \mathrm{SO}_{4}{ }^{-},(\mathbf{b}) \mathrm{PO}_{3}{ }^{-}$, and (c) $\mathrm{CaO}^{-}$.

\subsubsection{Dolomite Surfaces}

With regard to the dolomite surface treated with $1 \times 10^{-3} \mathrm{~mol} / \mathrm{L}$ of $\mathrm{H}_{2} \mathrm{SO}_{4}$, the secondary ions, including $\mathrm{CO}_{3}{ }^{-}, \mathrm{CaO}^{-}$, and $\mathrm{MgO}^{-}$, from the original dolomite surface were measured by the TOF-SIMS method (Figure 6). The $\mathrm{SO}_{4}{ }^{-}$was also present on the $\mathrm{H}_{2} \mathrm{SO}_{4}$-treated dolomite surface. These results revealed that $\mathrm{SO}_{4}{ }^{2-}$ can also adsorb on the dolomite surface. However, the amount of $\mathrm{SO}_{4}{ }^{-}$on the dolomite surface was less than that of $\mathrm{CO}_{3}{ }^{-}$.

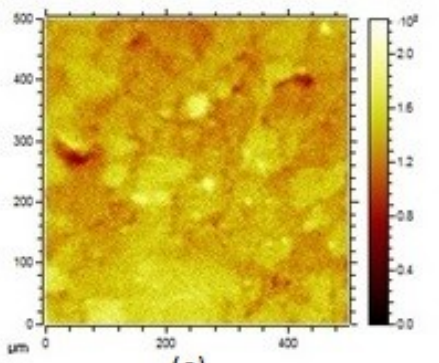

(a)

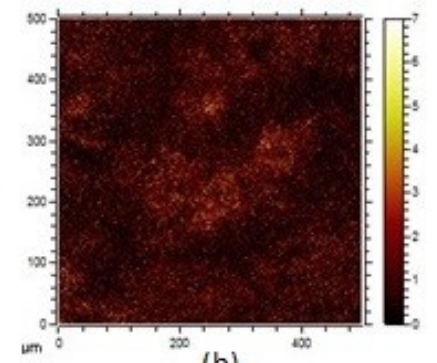

(b)

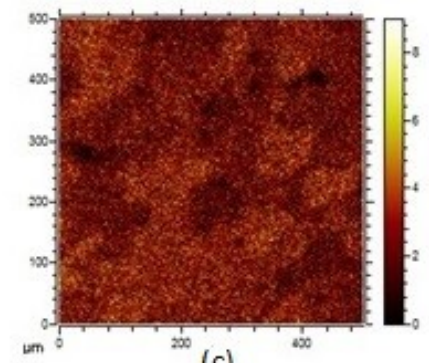

(c)

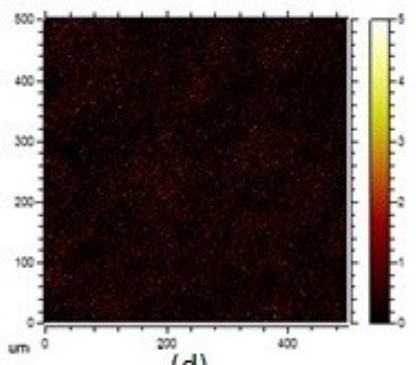

(d)

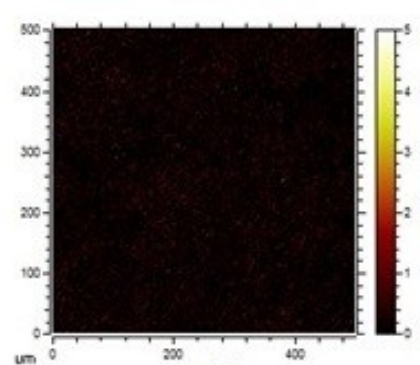

(e)

Figure 6. Two-dimensional distributions of ions on the dolomite surface $\left(500 \times 500 \mu \mathrm{m}^{2}\right)$ treated with $\mathrm{H}_{2} \mathrm{SO}_{4}\left(1 \times 10^{-3} \mathrm{~mol} / \mathrm{L}\right)$ : (a) overlap, (b) $\mathrm{SO}_{4}{ }^{-}$, (c) $\mathrm{CO}_{3}{ }^{-}$, (d) $\mathrm{CaO}^{-}$, and (e) $\mathrm{MgO}^{-}$.

When the $\mathrm{H}_{2} \mathrm{SO}_{4}$-treated dolomite was further conditioned with oleate, $\mathrm{SO}_{4}{ }^{-}$ions were still found on the mineral surface along with $\mathrm{CaO}^{-}, \mathrm{MgO}^{-}$, and $\mathrm{CO}_{3}^{-}$ions (Figure 7). Furthermore, a new molecular fragment (i.e., $\mathrm{C}_{2} \mathrm{H}_{3} \mathrm{O}_{2}{ }^{-}$) was measured on the dolomite surface. Evidently, the bombardment of the $\mathrm{Bi}_{3}{ }^{++}$beam to the oleate species broke the oleate molecule, thereby resulting in the generation of $\mathrm{C}_{2} \mathrm{H}_{3} \mathrm{O}_{2}{ }^{-}$. Moreover, the amount of $\mathrm{C}_{2} \mathrm{H}_{3} \mathrm{O}_{2}{ }^{-}$was evident on the dolomite surface, suggesting that oleate species and $\mathrm{SO}_{4}{ }^{2-}$ can simultaneously adsorb on the dolomite surface. In other words, the presence of $\mathrm{SO}_{4}{ }^{2-}$ on the dolomite surface did not prevent further adsorption of 
oleate. The 3D distribution results of these secondary ions/molecular fragments are summarized in Figure 8. Notably, $\mathrm{SO}_{4}{ }^{-}$and $\mathrm{C}_{2} \mathrm{H}_{3} \mathrm{O}_{2}{ }^{-}$islands were located on the top of the $\mathrm{H}_{2} \mathrm{SO}_{4}$-treated dolomite surface, while other ions were found throughout the entire measured region.

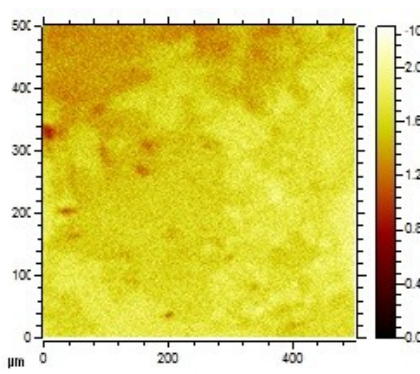

(a)

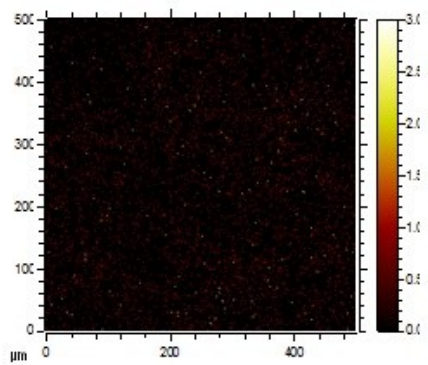

(d)

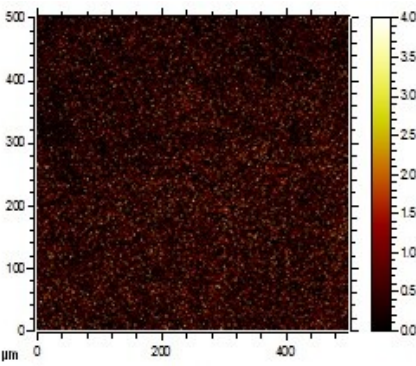

(b)

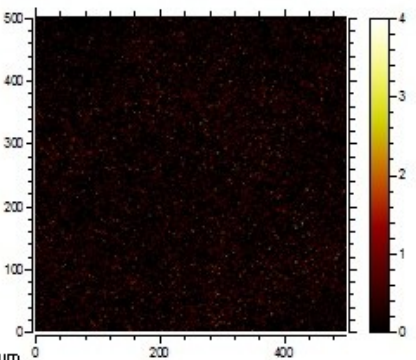

(e)

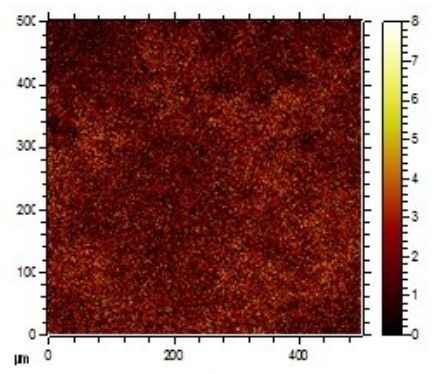

(c)

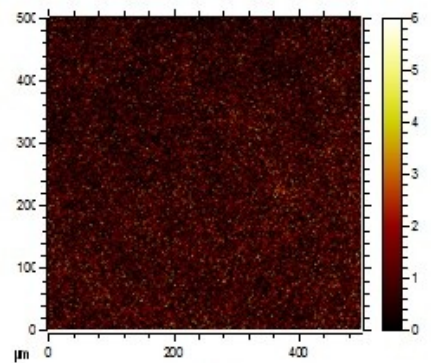

(f)

Figure 7. Two-dimensional distributions of ions on the dolomite surface $\left(500 \times 500 \mu \mathrm{m}^{2}\right)$ treated with $\mathrm{H}_{2} \mathrm{SO}_{4}\left(1 \times 10^{-3} \mathrm{~mol} / \mathrm{L}\right)$ and oleate $\left(2 \times 10^{-4} \mathrm{~mol} / \mathrm{L}\right)$ : (a) overlap, (b) $\mathrm{SO}_{4}{ }^{-}$, (c) $\mathrm{CO}_{3}{ }^{-}$, (d) $\mathrm{CaO}^{-}$, (e) $\mathrm{MgO}^{-}$, and (f) $\mathrm{C}_{2} \mathrm{H}_{3} \mathrm{O}_{2}^{-}$.

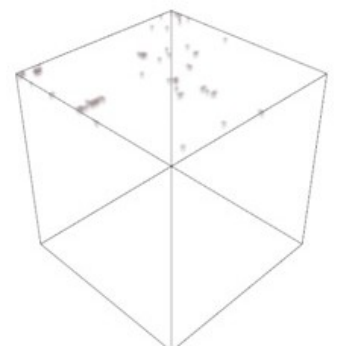

(a)

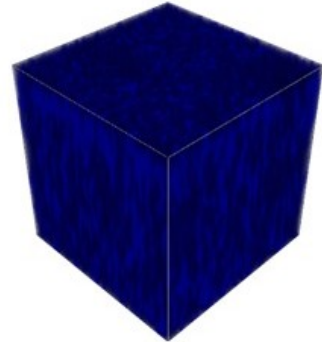

(b)

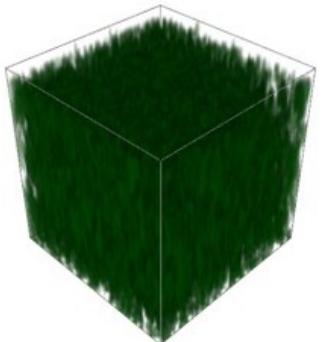

(c)

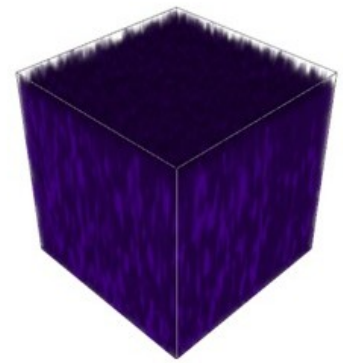

(d)

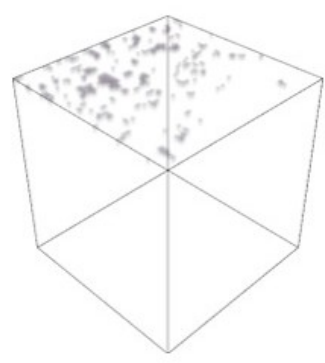

(e)

Figure 8. Three-dimensional distributions of ions on the FA surface treated with $\mathrm{H}_{2} \mathrm{SO}_{4}$ $\left(1 \times 10^{-3} \mathrm{~mol} / \mathrm{L}\right)$ and oleate $\left(2 \times 10^{-4} \mathrm{~mol} / \mathrm{L}\right):(\mathbf{a}) \mathrm{SO}_{4}{ }^{-}$, (b) $\mathrm{CO}_{3}{ }^{-}$, (c) $\mathrm{CaO}^{-}$, (d) $\mathrm{MgO}^{-}$, and (e) $\mathrm{C}_{2} \mathrm{H}_{3} \mathrm{O}_{2}^{-}$.

$\mathrm{Ca}^{2+}$ and $\mathrm{Mg}^{2+}$ ions exist on the dolomite surface. Similar to that on the FA surface, $\mathrm{SO}_{4}{ }^{2-}$ could also bind with $\mathrm{Ca}^{2+}$ on the dolomite surface forming surface $\mathrm{CaSO}_{4}$ species. $\mathrm{Mg}^{2+}$ on the dolomite surface cannot react with $\mathrm{SO}_{4}{ }^{2-}$ due to the high solubility of $\mathrm{MgSO}_{4}$. Thus, $\mathrm{Mg}$ sites on the surface 
were valuable for the adsorption of oleate. As previously mentioned, $\mathrm{Ca}^{2+}$ and $\mathrm{Mg}^{2+}$ on the deeper layer of mineral surface may have been exposed to the solution due to the dissociation of $\mathrm{CO}_{3}{ }^{2-}$ on the dolomite surface, which could also provide adsorption sites for oleate. In both events, oleate species can occur on the $\mathrm{H}_{2} \mathrm{SO}_{4}$-treated dolomite surface to generate a hydrophobic mineral surface.

Moreover, it seems that the measured density of $\mathrm{SO}_{4}{ }^{-}$on the dolomite surface was lower than that on the FA surface. The dissolution of the dolomite surface in the $\mathrm{H}_{2} \mathrm{SO}_{4}$ solution may release $\mathrm{Ca}^{2+}$ ions into the solution. In the bulk solution, $\mathrm{Ca}^{2+}$ ions could bond to $\mathrm{SO}_{4}{ }^{2-}$ to preferentially form a bulk precipitation of $\mathrm{CaSO}_{4}$. As a result, a portion of $\mathrm{SO}_{4}{ }^{2-}$ ions in the solution was consumed, resulting in a relatively low adsorption density on the dolomite surface.

\subsection{FTIR Study}

As stated in the Introduction section, the adsorption state of oleate species on a calcium-bearing mineral surface highly depends on the oleate concentration. In this section, the ATR-FTIR method was used to determine the oleate species on the dolomite surface at selected oleate concentrations. The ATR-FTIR spectra of FA samples were also measured for comparison.
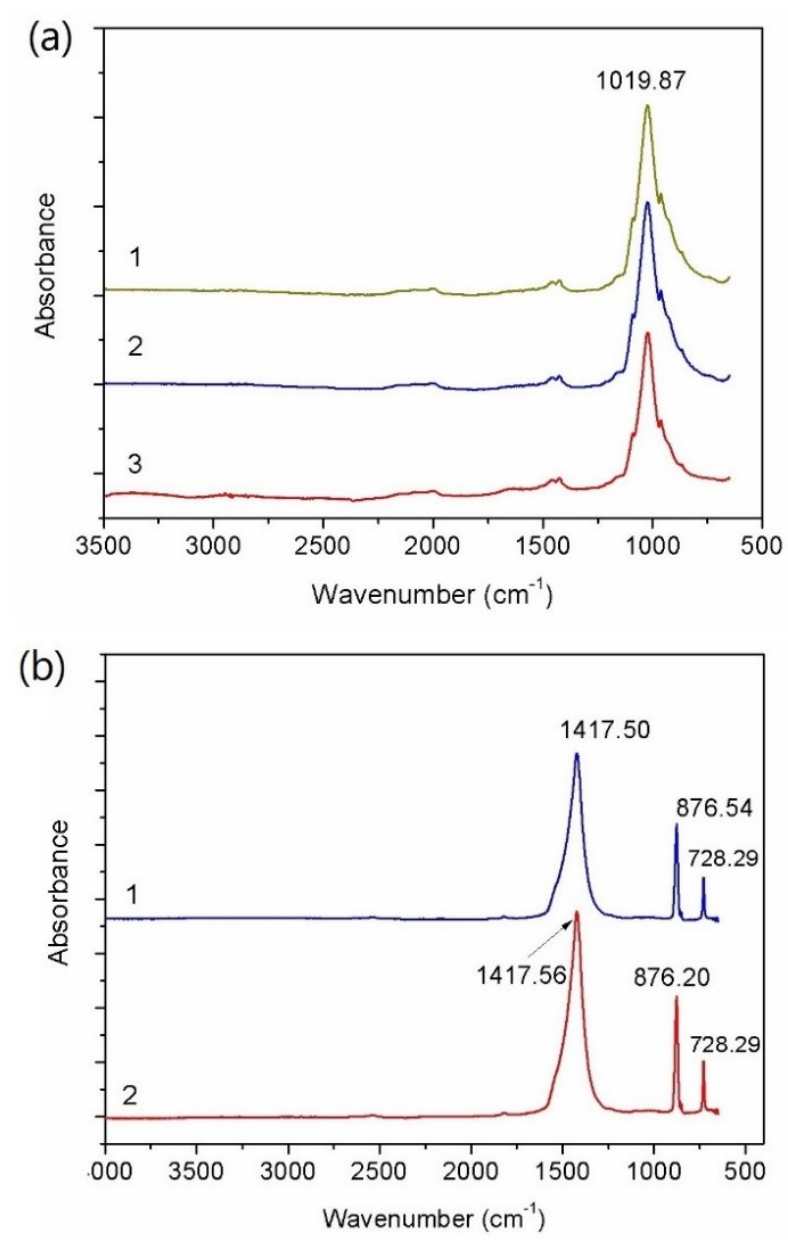

Figure 9. FTIR spectra of (a) FA samples (1-FA; 2-FA with $1 \times 10^{-3} \mathrm{~mol} / \mathrm{L}$ of $\mathrm{H}_{2} \mathrm{SO}_{4}$; 3 -FA with $1 \times 10^{-3} \mathrm{~mol} / \mathrm{L}$ of $\mathrm{H}_{2} \mathrm{SO}_{4}$ and $2 \times 10^{-4} \mathrm{~mol} / \mathrm{L}$ of oleate); and (b) dolomite samples (1-dolomite and 2 -dolomite with $1 \times 10^{-3} \mathrm{~mol} / \mathrm{L}$ of $\mathrm{H}_{2} \mathrm{SO}_{4}$ ).

Figure 9 summarizes the ATR-FTIR spectra of FA samples. In the spectrum of natural FA, the intense band at $1019 \mathrm{~cm}^{-1}$ can be assigned to the asymmetrical stretching vibration $\mathrm{PO}_{4}{ }^{3-}$ group [17]. This band was also observed in the spectrum of FA treated with $\mathrm{H}_{2} \mathrm{SO}_{4}\left(1 \times 10^{-3} \mathrm{~mol} / \mathrm{L}\right)$. Unexpectedly, the characteristic peaks of $\mathrm{SO}_{4}{ }^{2-}$ were not found for FA treated with $\mathrm{H}_{2} \mathrm{SO}_{4}$. The results 
show that FTIR is less sensitive in detecting the $\mathrm{CaSO}_{4}$ species on FA surface compared with the TOF-SIMS technique. In terms of FA treated with $\mathrm{H}_{2} \mathrm{SO}_{4}\left(1 \times 10^{-3} \mathrm{~mol} / \mathrm{L}\right)$ and oleate $\left(2 \times 10^{-4} \mathrm{~mol} / \mathrm{L}\right)$, the spectrum was similar to that of the natural FA. The characteristic peaks of the $\mathrm{CH}_{2}$ and $\mathrm{CH}_{3}$ vibrations did not occur in the spectrum. It appears that oleate cannot adsorb onto the FA surface conditioned with $\mathrm{H}_{2} \mathrm{SO}_{4}$, which is in accordance with the abovementioned TOF-SIMS results.

In the ATR-FTIR spectrum of the natural dolomite (Figure 9), the band at $1417 \mathrm{~cm}^{-1}$ was due to the asymmetric stretching of $\mathrm{CO}_{3}$ in dolomite. The peaks at $876 \mathrm{~cm}^{-1}$ and $729 \mathrm{~cm}^{-1}$ were attributed to the vibrations of $\mathrm{CO}_{3}$ of dolomite [18]. The peak at approximately $729 \mathrm{~cm}^{-1}$ was commonly used to distinguish dolomite from calcite $[18,19]$. Similar to the FTIR results of the FA sample, the spectrum of dolomite treated with $\mathrm{H}_{2} \mathrm{SO}_{4}$ was almost the same as that of natural dolomite. It is expected that the concentration of $\mathrm{CaSO}_{4}$ on dolomite surface was particularly limited to measurement by the ATR-FTIR method.
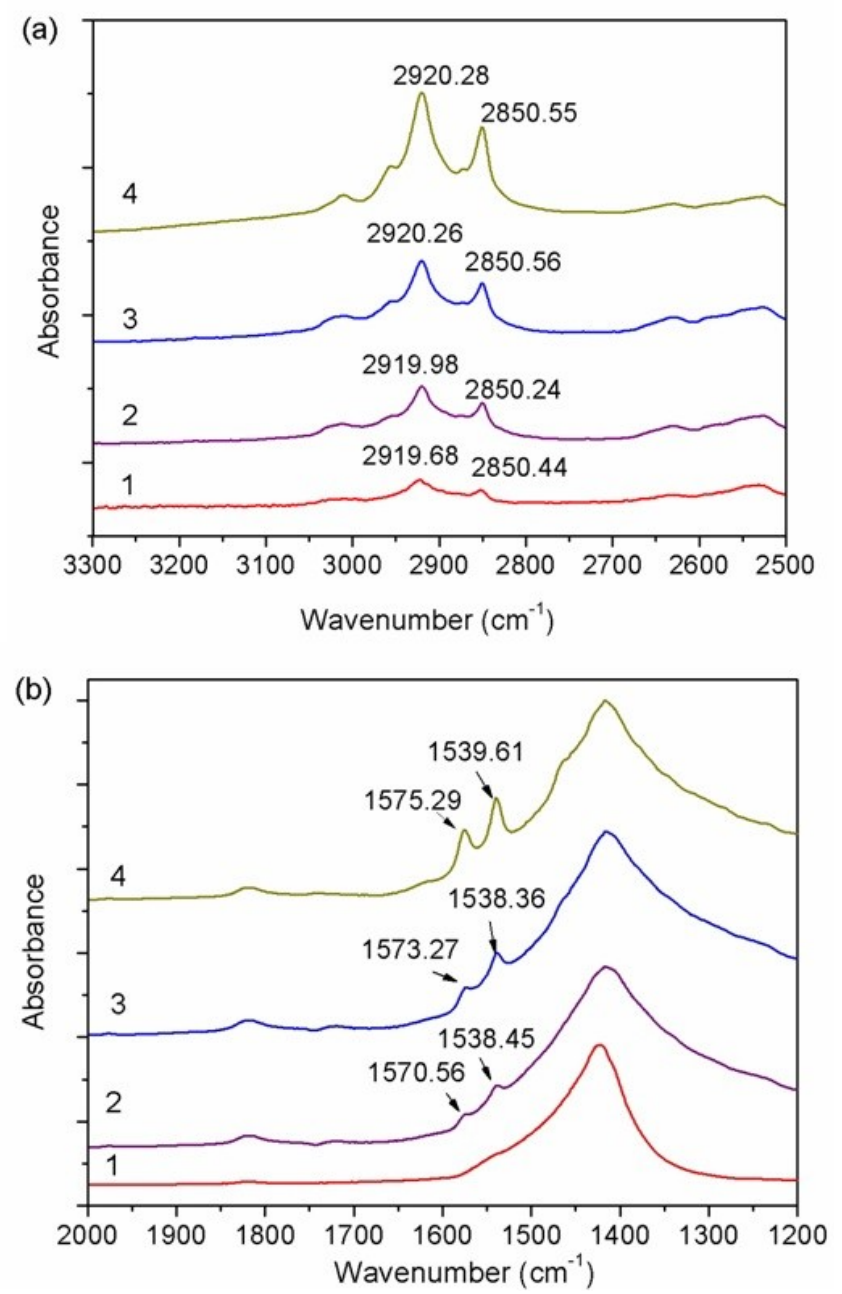

Figure 10. FTIR spectra (a) $3300-2500 \mathrm{~cm}^{-1}$; (b) $2000-1000 \mathrm{~cm}^{-1}$ of dolomite with $1 \times 10^{-3} \mathrm{~mol} / \mathrm{L}$ of $\mathrm{H}_{2} \mathrm{SO}_{4}$ and oleate at different concentrations $\left(1-1 \times 10^{-4} \mathrm{~mol} / \mathrm{L}, 2-2 \times 10^{-4} \mathrm{~mol} / \mathrm{L}\right.$, $3-2.5 \times 10^{-4} \mathrm{~mol} / \mathrm{L}$ and $\left.4-3 \times 10^{-4} \mathrm{~mol} / \mathrm{L}\right)$.

In terms of dolomite treated with $\mathrm{H}_{2} \mathrm{SO}_{4}\left(1 \times 10^{-3} \mathrm{~mol} / \mathrm{L}\right)$ and further with oleate (1-3 $\times 10^{-4} \mathrm{~mol} / \mathrm{L}$ ), two new adsorption bands at $2850 \mathrm{~cm}^{-1}$ (symmetry stretching of $\mathrm{CH}_{2}$ ) and $2920 \mathrm{~cm}^{-1}$ (asymmetry stretching of $\mathrm{CH}_{2}$ ) were observed in the spectrum (Figure 10) [20,21]. Furthermore, the intensities of these new bands became stronger with an increase in oleate concentration, which indicates that oleate species were adsorbed on the $\mathrm{H}_{2} \mathrm{SO}_{4}$-treated dolomite surface. 
The characteristic peaks of oleate species are in the range of $1800 \mathrm{~cm}^{-1}$ to $1300 \mathrm{~cm}^{-1}$ [10]. In the case of dolomite conditioned with $1 \times 10^{-4} \mathrm{~mol} / \mathrm{L}$ of oleate, the adsorption of oleate could not generate any new peaks in this wave number range. It seems that the adsorbed amount of oleate on the dolomtie surface was limited with $1 \times 10^{-4} \mathrm{~mol} / \mathrm{L}$ of the oleate, which cannot generate an IR signal in the spectrum from $1800 \mathrm{~cm}^{-1}$ to $1300 \mathrm{~cm}^{-1}$.

A doublet at $1570 \mathrm{~cm}^{-1}$ and $1538 \mathrm{~cm}^{-1}$ was found for dolomite with $2 \times 10^{-4} \mathrm{~mol} / \mathrm{L}$ of oleate (Figure 10). Furthermore, the peak at $1570 \mathrm{~cm}^{-1}$ shifted to a higher wave number side with an increase in oleate concentration. In contrast, the position of the peak at $1538 \mathrm{~cm}^{-1}$ barely changed in the examined oleate concentration range. Lu et al. assigned the doublet at $1574 \mathrm{~cm}^{-1}$ and $1538 \mathrm{~cm}^{-1}$ to the asymmetric vibration of carboxylate of $\mathrm{Ca}(\mathrm{OI})_{2}$ on the FA surface [10]. The vibration of carboxylate stretching of $\mathrm{Mg}(\mathrm{OI})_{2}$ also occurs at approximately $1572 \mathrm{~cm}^{-1}$ [22]. It is possible that $\mathrm{Mg}(\mathrm{OI})_{2}$ and $\mathrm{Ca}(\mathrm{OI})_{2}$ can exist on the $\mathrm{H}_{2} \mathrm{SO}_{4}$-treated dolomite surface. It seems that $\mathrm{SO}_{4}{ }^{2-}$ cannot bind with all the $\mathrm{Ca}^{2+}$ on the dolomite surface. Again, this may be caused by the dissociation of $\mathrm{CO}_{3}{ }^{2-}$ on the dolomite surface; a considerable number of $\mathrm{Ca}^{2+}$ ions can exist on the top of dolomite surface, and thus $\mathrm{SO}_{4}{ }^{2-}$ ions cannot interact with all the $\mathrm{Ca}^{2+}$ ions on the surface. Therefore, oleate can still adsorb onto some Ca sites on the dolomite surface to form precipitation of $\mathrm{Ca}(\mathrm{OI})_{2}$. On the other hand, it is also possible that the bulk precipitation of $\mathrm{Ca}(\mathrm{Ol})_{2}$ could adsorb onto the dolomite surface phycially.

Although it was difficult measure the $\mathrm{CaSO}_{4}$ species on the FA/dolomite surface with the ATR-FTIR method, the oleate species on the dolomite surface can be determined using this method. In addition, the above contact angle tests suggest that the contact angle of $\mathrm{H}_{2} \mathrm{SO}_{4}$-treated dolomite was approximately $110^{\circ}$ with $2 \times 10^{-4} \mathrm{~mol} / \mathrm{L}$ of oleate. At this oleate concentration, $\mathrm{Mg}(\mathrm{OI})_{2}$ and $/ \mathrm{or}$ $\mathrm{Ca}(\mathrm{OI})_{2}$ was measured on the mineral surface. Thus, it is concluded that the precipitation of $\mathrm{Mg}(\mathrm{OI})_{2}$ and/or $\mathrm{Ca}(\mathrm{OI})_{2}$ on the dolomite surface plays an important role in generating a hydrophobic surface.

\section{Conclusions}

$\mathrm{SO}_{4}{ }^{2-}$ ions can interact with $\mathrm{Ca}^{2+}$ ions on the FA surface to produce $\mathrm{CaSO}_{4}$ species, which prevents the adsorption of oleate on the Ca sites on the FA surface to generate a hydrophobic surface. Hence, a poor FA recovery is obtained.

As expected, $\mathrm{CaSO}_{4}$ species can also form on the $\mathrm{H}_{2} \mathrm{SO}_{4}$-treated dolomite surface. $\mathrm{Mg}^{2+}$ ions on the dolomite surface cannot be involved in the interaction with $\mathrm{SO}_{4}{ }^{2-}$ ions. We hypothesize that a considerable number of metal atoms on the dolomite surface might be exposed to the solution considering the dissociation of $\mathrm{CO}_{3}{ }^{2-}$ on the dolomite surface in the solution of $\mathrm{H}_{2} \mathrm{SO}_{4}$, and thus $\mathrm{SO}_{4}{ }^{2-}$ ions cannot bind with all of the $\mathrm{Ca}^{2+}$ ions on the dolomite surface. As a result, oleate species still adsorb on some $\mathrm{Ca}$ and $\mathrm{Mg}$ sites on the dolomite surface. In addition, the precipitation of $\mathrm{Mg}(\mathrm{OI})_{2}$ and/or $\mathrm{Ca}(\mathrm{OI})_{2}$ on the $\mathrm{H}_{2} \mathrm{SO}_{4}$-treated dolomite surface accounts for the hydrophobicity of dolomite surface using $2 \times 10^{-4} \mathrm{~mol} / \mathrm{L}$ of oleate. In this regard, the $\mathrm{H}_{2} \mathrm{SO}_{4}$-treated dolomite still could be collected by oleate at this concentration.

Author Contributions: Q.C. and D.L. conceived and designed the experiments; H.Z. performed the experiments; X.Y. and H.L. analyzed the data; D.L. contributed reagents/materials/analysis tools; H.Z. wrote the paper.

Funding: This research was funded by the Analysis and Testing Foundation of Kunming University of Science and Technology (China).

Conflicts of Interest: The authors declare no conflict of interest.

\section{References}

1. Prasad, M.; Majumder, A.K.; Rao, T.C. Reverse flotation of sedimentary calcareous/dolomitic rock phosphate ore-An overview. Min. Metall. Explor. 2000, 17, 49-55. [CrossRef]

2. Zheng, X.; Smith, R.W. Dolomite depressants in the flotation of apatite and collophane from dolomite. Miner. Eng. 1997, 10, 537-545. [CrossRef] 
3. Liu, X.; Luo, H.; Cheng, R.; Li, C.; Zhang, J. Effect of citric acid and flotation performance of combined depressant on collophanite ore. Miner. Eng. 2017, 109, 162-168. [CrossRef]

4. Ge, Y.Y.; Gan, S.P.; Zeng, X.B.; Yu, Y.F. Double reverse flotation process of collophanite and regulating froth action. Trans. Nonferr. Met. Soc. China 2008, 18, 449-453. [CrossRef]

5. Sis, H.; Chander, S. Reagents used in the flotation of phosphate ores: A critical review. Miner. Eng. 2003, 16, 577-585. [CrossRef]

6. Karlkvist, T.; Patra, A.; Rao, K.H.; Bordes, R.; Holmberg, K. Flotation selectivity of novel alkyl dicarboxylate reagents for apatite-calcite separation. J. Colloid Interface Sci. 2015, 445, 40-47. [CrossRef]

7. Yu, J.; Ge, Y.; Guo, X.; Guo, W. The depression effect and mechanism of NSFC on dolomite in the flotation of phosphate ore. Sep. Purif. Technol. 2016, 161, 88-95. [CrossRef]

8. Liu, X.; Li, C.; Luo, H.; Cheng, R.; Liu, F. Selective reverse flotation of apatite from dolomite in collophanite ore using saponified gutter oil fatty acid as a collector. Int. J. Min. Process. 2017, 165. [CrossRef]

9. Mohammadkhani, M.; Noaparast, M.; Shafaei, S.Z.; Amini, A.; Amini, E.; Abdollahi, H. Double reverse flotation of a very low grade sedimentary phosphate rock, rich in carbonate and silicate. Int. J. Min. Process. 2011, 100, 157-165. [CrossRef]

10. Lu, Y.; Drelich, J.; Miller, J.D. Oleate adsorption at an apatite surface studied by ex-situ FTIR internal reflection spectroscopy. J. Colloid Interface Sci. 1998, 202, 462-476. [CrossRef]

11. Rao, K.H.; Antti, B.M.; Forssberg, E. Mechanism of oleate interaction on salt-type minerals, Part II. Adsorption and electrokinetic studies of apatite in the presence of sodium oleate and sodium metasilicate. Int. J. Min. Process. 1990, 28, 59-79. [CrossRef]

12. DR, V.; DS, R.; SD, D. Electrokinetic properties of hydroxyapatite under flotation conditions. J. Colloid Interface Sci. 2010, 343, 239-245. [CrossRef]

13. Sis, H.; Chander, S. Adsorption and contact angle of single and binary mixtures of surfactants on apatite. Miner. Eng. 2003, 16, 839-848. [CrossRef]

14. Sodhi, R.N.S. Time-of-flight secondary ion mass spectrometry (TOF-SIMS):-Versatility in chemical and imaging surface analysis. Analyst 2004, 129, 483-487. [CrossRef] [PubMed]

15. Benninghoven, A. Chemical analysis of inorganic and organic surfaces and thin films by static time-of-flight secondary ion sass spectrometry (TOF-SIMS). Angew. Chem. Int. Ed. 2010, 33, 1023-1043. [CrossRef]

16. Chehreh Chelgani, S.; Hart, B. TOF-SIMS studies of surface chemistry of minerals subjected to flotation separation-A review. Miner. Eng. 2014, 57, 1-11. [CrossRef]

17. Albano, M.P.; Garrido, L.B. Processing of concentrated aqueous fluorapatite suspensions by slip casting. J. Mater. Sci. 2011, 46, 5117-5128. [CrossRef]

18. Müller, C.M.; Pejcic, B.; Esteban, L.; Piane, C.D.; Raven, M.; Mizaikoff, B. Infrared Attenuated Total Reflectance Spectroscopy: An Innovative Strategy for Analyzing Mineral Components in Energy Relevant Systems. Sci. Rep. 2014, 4, 6764. [CrossRef]

19. Gunasekaran, S.; Anbalagan, G.; Pandi, S. Raman and infrared spectra of carbonates of calcite structure. J. Raman Spectrosc. 2010, 37, 892-899. [CrossRef]

20. Huang, Z.; Cheng, C.; Li, L.; Guo, Z.; He, G.; Yu, X.; Liu, R.; Han, H.; Deng, L.; Fu, W. Morpholine-based gemini surfactant: Synthesis and its application for reverse froth flotation of carnallite ore in potassium fertilizer production. J. Agric. Food Chem. 2018, 66, 13126-13132. [CrossRef]

21. Liu, C.; Feng, Q.; Zhang, G.; Ma, W.; Meng, Q.; Chen, Y. Effects of lead ions on the flotation of hemimorphite using sodium oleate. Miner. Eng. 2016, 89, 163-167. [CrossRef]

22. Wensel, R.W.; Penaloza, M.; Cross, W.M.; Winter, R.M.; Kellar, J.J. Adsorption behavior of oleate on $\mathrm{Mg}(\mathrm{OH})_{2}$ as revealed by FT-IR spectroscopy. Langmuir 1995, 11, 4593-4595. [CrossRef]

(C) 2019 by the authors. Licensee MDPI, Basel, Switzerland. This article is an open access article distributed under the terms and conditions of the Creative Commons Attribution (CC BY) license (http:/ / creativecommons.org/licenses/by/4.0/). 